\title{
Medicinal plant knowledge of the Panchase region in the Middle Hills of the Nepalese Himalayas
}

\author{
K. R. Bhattarai ${ }^{1}$, I. E. Måren ${ }^{2}$ and R. P. Chaudhary ${ }^{3}$
}

\begin{abstract}
Use of plants as medicine has been practiced all over the world since the dawn of human civilisation. In the Himalayas, many medicinal plants yield essential ecosystem services/ benefits for the subsistence farmers, many of which grow in the forest ecosystem. However, documentation of traditional medicine and medicinal plants used by local communities is rather poor in Nepal. Panchase forest, Central Nepal, is home of many wild plants, used in traditional medicine, and a livelihood source for many ethnic groups. This study was conducted to document medicinal plant knowledge and plant use in the treatment of different ailments. To explore the ethnobotanical knowledge interviews were conducted with local healers, plant traders and knowledgeable villagers. The study provides information on 45 plant species, belonging to 32 families under 44 genera. The studied medicinal plants were found to be useful for treating 34 different ailments. The study which has $57 \%$ resemblance with previous studies. We conclude that a wealth of ethnobotanical knowledge still persists in the Panchase region. However, due to land use change and migration it needs to be preserved for the future through extensive publications and disseminations.
\end{abstract}

Key words: Ethnobotany, Panchase, medicinal plants, ailments

$\mathrm{T}$ he UN-commissioned Millennium Ecosystem Assessment (MA, 2005) finds that the increasing demands on ecosystem services over the past 50 years have been fulfilled at the cost of ecosystem degradation and diversity loss. The MA stresses that immediate action is needed to enhance the conservation and sustainable use of ecosystems to maintain their provisions/services to human well-being. Population growth, increasing wealth and changing consumption patterns, combined with land use and climate change, are exerting strong pressures on biodiversity, thereby, this posessing a challenge to biodiversity conservation and consequently it's provisioning of ecosystem services.

Nepal is part of the Himalayan biodiversity hotspot and one of the poorest countries in the world with a growing population and increasing demands on ecosystem services. Human settlement has existed in the Himalayas for thousands of years and the use of medicinal plants and traditional medicinal practice has been developed over the same time. Traditional medicinal practice has maintained its popularity in many parts of Himalayas even after the introduction of Western medicine. The traditional medicinal knowledge has been developed into a successful system of medicine, namely Ayurveda, where hundreds of plant species were documented as medicinal plants almost 3000 years ago. The traditional herbal medicine possesses great significance in Nepal, and the interest in herbal medicine has gradually increased over recent years (Burlakoti and Kunwar, 2008). However, proper documentation of traditional medicinal knowledge within different ethnic communities and tribes has not yet been conducted. Nepal Biodiversity Strategy (2002) has highlighted the urgent need for the documentation of indigenous knowledge for conservation of the Himalayan biodiversity (HMGN-MFSC, 2002).

Within the Himalayas, forests are the richest habitats for medicinal plants forming the basis for several ecosystem services (Ives, 1987). Panchase is a sacred region where many Yogis used to live

\footnotetext{
${ }^{1}$ National Herbarium and Plant Laboratories, Department of Plant Resources, Nepal. Email: bhattaraikhemraj@gmail.com

${ }^{2}$ Bjerknes Centre for Climate Research, University of Bergen, Norway

${ }^{3}$ Central Department of Botany, Tribhuvan University, Kirtipur, Kathmandu, Nepal
} 
and where they practiced herbal medicines in the past. The tradition of Yogis living at the top of Panchase has been discontinued over the past years. Consequently, the knowledge of the local villagers may also contribute to valuable information about the historical use of medicinal plants of the area. Although some studies have been conducted to document biodiversity of this region (Koirala, 1998), the documentation of ethnobotanical information has been lacking. The aim of this study is to explore the plant based indigenous knowledge of the people living in adjoining villages to the Panchase forest.

\section{Materials and methods}

\section{Study site}

Panchase is situated in the Middle Hills of Nepal, just west of Pokhara, between the longitudes $83^{\circ} 45^{\prime}$ to $83^{\circ} 57^{\prime} \mathrm{E}$ and the latitudes $28^{\circ} 12^{\prime}$ to $28^{\circ} 18^{\prime} \mathrm{N}$. Altitude ranges from 855 masl at the Harpan River to 2517 masl at the peak of Panchase whereas the forest ranges from 1450 masl to the peak. The forest covers an approximate area of $10-12 \mathrm{~km}^{2}$. The Panchase Mountain is the origin of many rivers and tributaries supplying water to the villages and a primary source area for Phewa Lake. Climate is subtropical at lower altitudes and moist temperate at elevation above $2100 \mathrm{~m}$. The Panchase forest is spread over three districts; Kaski, Parbat and Syangja, and with five different Village Development Committees (VDCs). The ethnic composition of the area constitutes Brahmin, Chhetri, Gurung, Bishwokarma, Nepali, Pariyar, Magar and Thakali, where generally Gurung communities inhabit higher elevation and Brahmin and Chhetri dominate the valley bottom. Of these, Gurung and Magar are indigenous to the area and Bishwokarma, Nepali and Pariyar are the disadvantaged groups. Approximately 40000 people live in the adjoining villages and depend upon the forest for their livelihood (fodder, firewood, timber, edible and medicinal plants). This region is densely populated by subsistence farmers and livestock rearing is an integral part of their livelihood.

\section{Sampling}

Field study was carried out over three periods; March-April 2010, April 2011 and November 2011. Primary data regarding plant species traditional knowledge used and treated ailments were collected through group discussions, informal meetings; cross-checking and field observations ( Kunwar et al., 2010). Field survey was conducted in all adjoining VDCs of Kaski, Parbat and Syangja districts. In Kaski district, local people from Bhadhuare, Damdame, Kutmidanda, Sidhane, Tamagi, and Bhaudhauredeurali were interviewed. The local people of Bange of Syangja district and Chitre and Aarthar of Parbat district were consulted. Among the respondents, knowledgeable women were the dominant group which was followed by knowledgeable older men and traditional healers. Species were identified on site by using reference literatures. Unrecognized plants were identified at the National Herbarium and Plant Laboratory at Godawari, Lalitpur. Plants were collected and displayed during group discussions, interviews and consultations.

During group discussions and interviews information was sought about medicinal use, local names and any other uses of the particular plant species. Ethnobotany and chemical properties of the species were checked with published literature (Manandhar, 2002; Baral and Kurmi, 2006; Bhattarai and Ghimire, 2006; Kunwar et al., 2010). Whereas the Ayurvedic system and the Unani system of medicinal use was verified with literature (Kirtikar and Basu, 1980).

\section{Results and discussion}

\section{Medicinal plants and traditional medicine}

We found 45 medicinal plant species belonging to 32 families under 44 genera (Table 1). These 45 locally used medicinal plants were found to treat 34 different ailments. The family namely, Rosaceae include the highest number of medicinal species (four), followed by Moraceae and Asteraceae (each three) and Pteridaceae (two). About $57 \%$ of the indigenous use of plant species at Panchase resembled use documented by earlier ethnobotanical reports from other parts of Nepal. The majority of plant species from the forested areas of Panchase have more affinity towards the Ayurvedic system of medicine than the Unani system of medicine (Table 2).

Among the 34 different ailments reported in the present study wounds, dysentery and fever are 
considered most common and the majority of the medicinal plants are used for the treatment of these ailments. The plant parts used for herbal remedies were bark, leaf, latex, rhizome and whole plant. In the majority of cases, whole plant or leaf extract is taken for treatment. Among the 45 species there are four species which are used to prepare yeast. The yeast is used to ferment the local alcohol raksi for the Gurungs and Newars and other schedule casts like Biswokarma, Nepali and Pariyar also prepare alcohol themselves.

People of this region have deep knowledge on herbal medicine and traditional medicinal plant practice, practiced since ancient times. There is still a lack of modern hospital facilities and modern medicine so people heavily rely upon local medicinal plants for their primary health care. The present study showed that traditional plant based knowledge has flourished in the periphery of the Panchase region. It might be not only be due to long travel and higher costs of using modern medicine, but traditional medicinal practice has been more culturally acceptable, globally (Brown, 1994), as well as in Nepal (Chaudhary, 1998). Many of the most used plant species in the present study area are also used in other parts of Nepal (Manandhar, 2002; Baral and Kurmi, 2006; Bhattarai and Ghimire, 2006). Very few species, e.g. Paris polyphylla and Swertia chirayita, are harvested commercially; the majority of species are folkloric in importance. International treaties and policies have over the last decades emphasized the need to create greater awareness and a wider application of indigenous knowledge for sustainable biological resource management and Nepal needs to contribute to this effort.

\section{Pharmacology and chemical properties of medicinal plants}

Some of the plants used as medicine in the Panchase region are unknown to Ayurvedic and Unani practice. This might be due to the fact that the Ayurvedic system of medicine where plants were documented as Ayurvedic medicinal plants was developed a long time back and the use of undocumented plant species was developed later through the practices and experiences of local people. The Unani system of medicine is mostly practiced in Muslim communities which is lacking in the Panchase region. In the literature relatively few species have been found with their Unani use (Kirtikar and Basu, 1980,). Documented chemical properties of all species could not be found. This indicates that traditional knowledge has existed and been practiced in rural areas but the knowledge has not been streamlined for pharmacological test and use yet. Among the 45 medicinal plant species found in the study area only 20 species could be traced for their main chemical constituents. This shows that phytochemistry may be an essential component to research in this region. According to the Ayurvedic system of medicine, some plants like Artemisia dubia and Cannabis sativa have been used as anthelmentic and to cure rheumatism but these are actually used to cure skin diseases and to control bleeding from wounds in the Panchase region. Phytochemistry studies need whether the chemical properties of the plant really document results in support of the traditional use.

When comparing the Ayurvedic system and the Unani system, both have certain similarities and both systems have the affinity towards to use of plant species for curing an array of ailments (Kirtikar and Basu, 1980).

\section{Acknowledgements}

Thanks to Basudha Gurung, Dil Bahadur Bhattarai, Lila N. Sharma, Bishnu Chapagain, Ashok Chaudhary, Kuber Bhatta, Rupesh Gurung and Keith McInturff for field work assistance, and to all the villagers around Panchase who participated in the project. The Machhapuchhare Development Organisation is acknowledged for its cooperation. Financial support was received from the Norwegian Research Council (190153/ V10) and Grolle Olsens Legat.

\section{References}

Agrawal, V. and Chauhan, B.M. 1988. A study of composition and hypolipidemic effects of dietary fiber from some plant foods. Plant Foods and Human Nutrition 38 (2): 377-381.

Ambasta, S.P., Ramchandran, K., Kashyapa, K. and Chanda, R. 1992. The Useful Plants of India. Council of Science and Industrial Research (CSIR), New Delhi, India.

Anonymous. 1976. Medicinal Plant of Nepal. Bulletin No. 3. His Majesty Government of Nepal, Departnment of Medicinal plants, Thapathali, Kathamndu, Nepal. 
Baral, S.R. and Kurmi, P.P. 2006. A Compendium of Medicinal Plants in Nepal. Mrs, Rachana Sharma, Kathmandu-7, Nepal.

Bhattarai, K.R. and Ghimire, M.D. 2006. Cultivation and Sustainable Harvesting of Commercially Important Medicinal and Aromatics Plants of Nepal. Heritage Research and Development Center, Kathmandu, Nepal.

Bhattarai, N.K. 1989. Traditional phytotherapy among the Sherpa of Helambu. J. of Ethnopharmacology 27(1/2): 45-55.

Brown, K. 1994. Approaches to valuing plant medicines: the economics of culture or culture of economics? Biodiversity and Conservation 3: 734-750.

Buckingham, J. 1994. Dictionary of Natural Products, Vol.7. Champan and Hall, Logndon, UK.

Burlakoti, C. and Kunwar, R. M. 2008. Folk herbal medicine of Mahakali watershed area, Nepal. In Medicinal Plants: An Anthology of Contemporary Research (eds.) Jha, P. K., Karmarcharya, S. B., Chhetri, M. K., Thapa, C. B. snd Shrestha, B. B. Ecological Society, Kathmandu, Nepal, 187-193.

Chapagain, D.J., Joshi, S.D. and Jnawali, S.R. 2004. Indigenouse use of medicinal plants by tharu community in southern buffer zone of Bardia National Park, Nepal. Proceeding of National Congress on Science and Technology 738-751.

Chaudhary, R. P. 1998. Biodiversity in Nepal: Status and Conservation. S. Devi, Saharanpur, India and Tecpress Books, Bangkok, Thailand.

DPR. 2007. Medicinal Plants Bull. of the Department of Plant Resources No. 28. of Nepal (revised). Department of Plant Resources, Kathamndu, Nepal.

HMGN-MFSC 2002. Nepal Biodiversity Strategy. His Majesty's Government of Nepal, Ministry of Forest and Soil Conservation., Kathmandu, Nepal.
Husain , A., Viramani, O. P., Popali, S. P., Mishra, L.N., Gupta, M. M., Sirvatava, G. N, Abraham, Z. and Singh, A. K. 1992. Dictionary of Indian Medicinal Plants. Central Institute of Medicinal and Aromatic Plants, Lucknow, India.

IUCN. 2004. Nepal: National Register of Medicinal and Aromatics Plants of Nepal. The World Conservation Union, Nepal.

Ives, J.D. 1987. The theory of himalayan environmental degradation: Its validity and Application Challenged. Mountain Research and Development 7: 189-199.

Joshi, S. G. 2006. Medicinal Plants. Oxford and IBH publishing, New Delhi, India.

Kirtikar, R. K. and Basu, B. D. 1980. Indian Medicinal Plants Vol.I.-Vol. IV. Bisen Singh Mahendra Pal Singh, Dehradun, India.

Koirala, R. 1998. Botanical diversity within the project area of Machhapuchhare Development Organization, Bhadaure/ Tamagi, VDC VDC Kaski District, Nepal.

Kunwar, R. M., Shrestha, K. P., and Bussman, R. W. 2010. Traditional herbal medicine in Far-west Nepal a pharmacological appraisal. J. of Ethnobiology and Ethnomedicine 6/35: 1-18.

Manandhar, N. P. 2002. Plant and People of Nepal. Timber Press, Oregon, USA.

Rajbhandari, K. R. 2001. Ethnobotany of Nepal. Ethnobotanical Society of Nepal, Central Department of Botany,TU, Kirtipur, Kathmandu, Nepal.

Rastogi, R. P. and Marhotra, B. N. 1979. In $A$ compendium of medicinal plants, Volume II. Central Drug Research Institute, Lucknow, Publication and Information Directorate, New Delhi, India.

Watanabe, T., Rajbhandari, K. R., Malla, K. J., and Yahara, S. 2006. A Handbook of Medicinal Plants of Nepal. Ayur Seed Life Environmental Institute, Japan. 
Table 1: Plant species used for medicinal purposes from the forest ecosystem at Panchase, Central Nepal.

\begin{tabular}{|c|c|c|c|}
\hline Scientific name & Family name & Local name & Plant parts used \\
\hline Achyranthus aspera $\mathrm{L}$. & Amaranthaceae & Apaamarga & Root \\
\hline Aesculus indica (Colebr. Ex Cambess) & Hippocastanaceae & Lekhpangra & Seed \\
\hline Aloe vera $(\mathrm{L})$ Burm $\mathrm{f}$ & Liliaceae & Ghiukumari & Leaf \\
\hline Artemisia indica Willd. & Asteraceae & Titepati & Leaf, stem \\
\hline Artocarpus lakoocha Wall. ex Roxb. & Moraceae & Badahar & Bark \\
\hline Azadirachta indica A. Juss. & Meliaceae & Neem & Leaf \\
\hline Bauhinia variegata $\mathrm{L}$. & Fabaceae & Koiralo & Flower \\
\hline Boebmeria platyphylla D. Don & Urticaceae & Kamle & Root \\
\hline Cannabis sativa L. Syn. C. indica & Cannabaceae & Bhang & Leaf, stem \\
\hline Chelanthes tenuifolia (Burm.f.)Sw & Pteridaceae & Kalisinka & Rhizome \\
\hline Cissampelos pareira L. & Menispermaceae & Batulpate & Root \\
\hline Clematis montana Buch.-Ham.ex Dc. & Ranunculaceae & Jungelahara & Root \\
\hline Curcuma angustifolia Roxb. & Zingiberaceae & Haldi & Rhizome \\
\hline Daphne bholua Buch-Ham. Ex D. Don. & Thymeleceae & Kajapate & Seeds, root \\
\hline Drymaria diandra $\mathrm{Bl}$. & Caryophyllaceae & Abijalo & Whole plant \\
\hline Engelhardtia spicata Leschen ex Blume & Juglandaceae & Mauwa & Flower \\
\hline Euphorbia birta L. & Euphorbiaceae & Dhudhe & Plant latex \\
\hline Ficus auriculata Laur & Moraceae & Nibaro & Fruit, bark \\
\hline Ficus plamata Forssk & Moraceae & Bedulo & Latex, fruit \\
\hline Fragaria nubicola Lindl & Rosacae & Bhuikafal & Fruit \\
\hline Hibiscus mutabilis $\mathrm{L}$. & Malvaceae & Baramasephool & Leaf, flower \\
\hline Innula cappa Buch-Ham. Ex D. Don.DC. & Asteraceae & Rasnaa & Leaf, twig \\
\hline Lobelia pyramidalis Wall. & Campanulaceae & Aklebir & Leaf, twig \\
\hline Maesa chisia Buch-Hamex D. Don & Myrsinaceae & Bilaune & Leaf, fruits \\
\hline Myrica esculenta Buch-Ham ex D. Don & Myricaceae & Kafal & Fruits, bark \\
\hline Nephrolepis auriculata (L.) Trimen & Nephrolepidaceae & Paniamala & Tuber \\
\hline Oxalis corniculata $\mathrm{L}$. & Oxalidaceae & Chariamilo & Whole plant \\
\hline Paris polyphylla Sm. & Liliaceae & Satuwa & Rhizome \\
\hline Persicaria barbata $(\mathrm{L})$ Hara & Polygonaceae & Pirejhar & Leaf \\
\hline Potentilla fulgens Wall. ex Hook. & Rosaceae & Bajardanti & Whole plant \\
\hline Pteris biaurita L. & Pteridiaceae & Sotar & Leaves and rhizome \\
\hline Pyracantha creulata (D Don) M Roemer & Rosaceae & Ghangaru & Fruits \\
\hline Quercus lanata $\mathrm{Sm}$. & Fagaceae & Banjha & Hard resin \\
\hline Rubus ellipticus Sm. & Rosaceae & Auselu & Fruit \\
\hline Sapium insigne (Royle) Benth. ex Hook. f. & Euphorbiaceae & Khirro & Latex \\
\hline Schima wallichii (DC.) Korth. & Theaceae & Chilaune & Bark, young plant \\
\hline Scutellaria discolor Colebr. & Labiatae & Dampate & Leaf, twig \\
\hline Smilax aspera $\mathrm{L}$. & Smilaceae & Kukurdaino & Root \\
\hline Solanum capsicoides All. & Solanaceae & Kantakari & Fruit \\
\hline Spilanthes paniculata Wall. & Asteraceae & Marathi & Flower head \\
\hline Swertia chirayita (Roxb. ex Fleming) Karsten & Gentianaceae & Chirayaito & Whole plant \\
\hline Taxus wallichiana (Zucc.) Pilger & Taxaceae & Lothsalla & Leaf, twig \\
\hline Tectaria caudunata (Wall. ex J Sm) C Chr & Dryopteridaceae & Kuthkure & Rhizome \\
\hline Tinospora sinensis (Lour.) Merr. & Menispermaceae & Gurjo & Stem \\
\hline Vitex negundo L. & Verbenaceae & Simali & Leaf \\
\hline
\end{tabular}




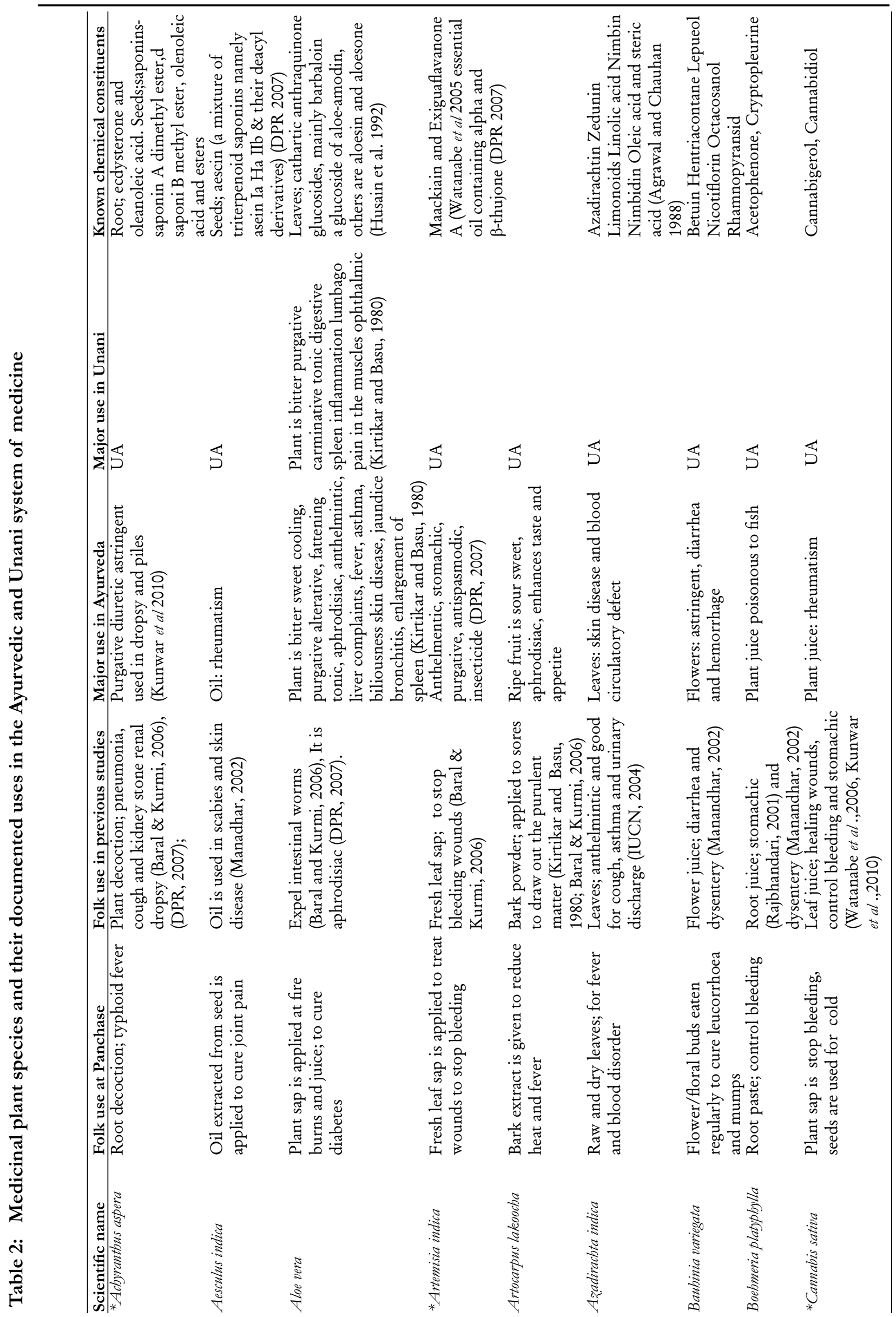




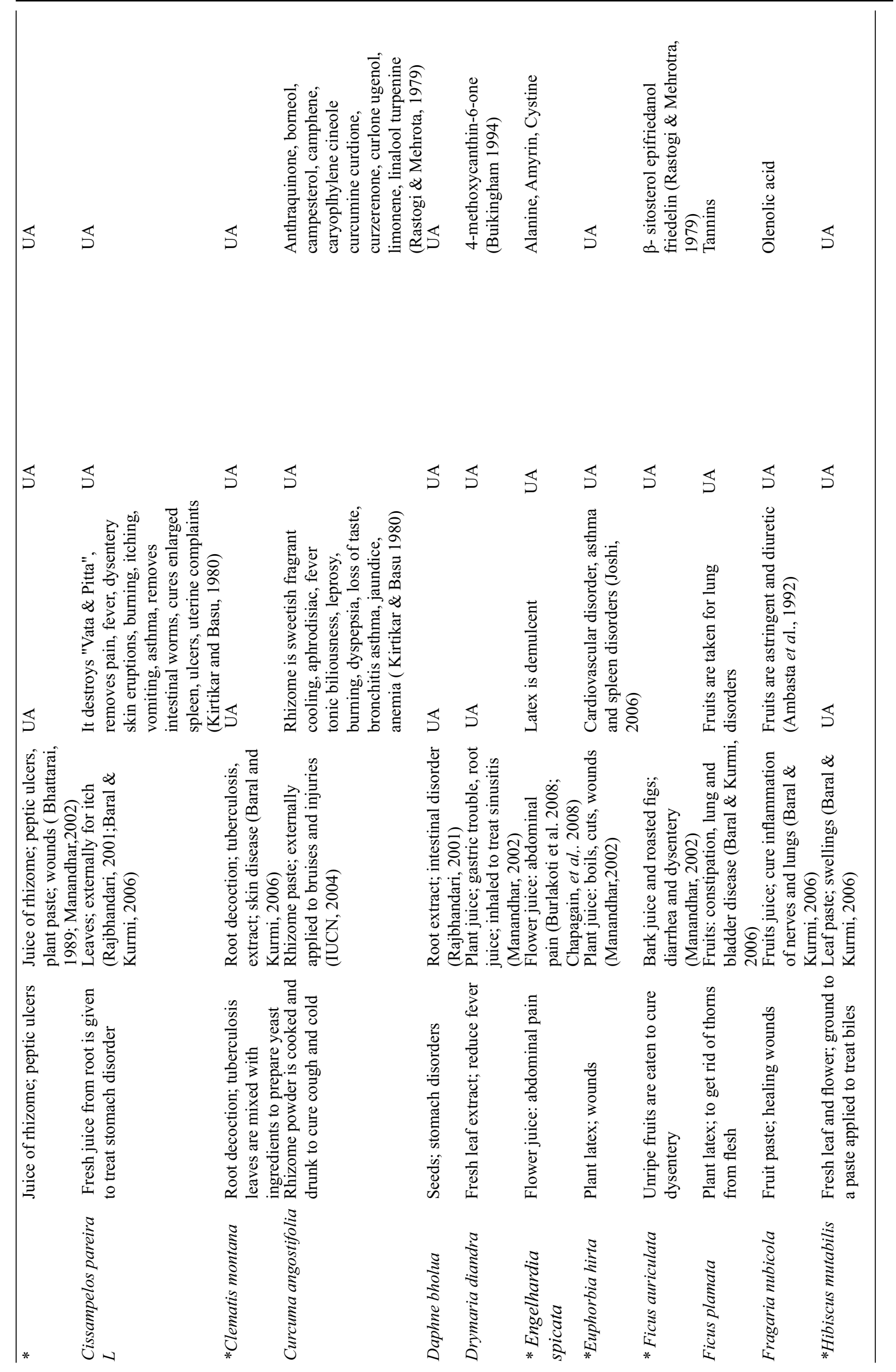




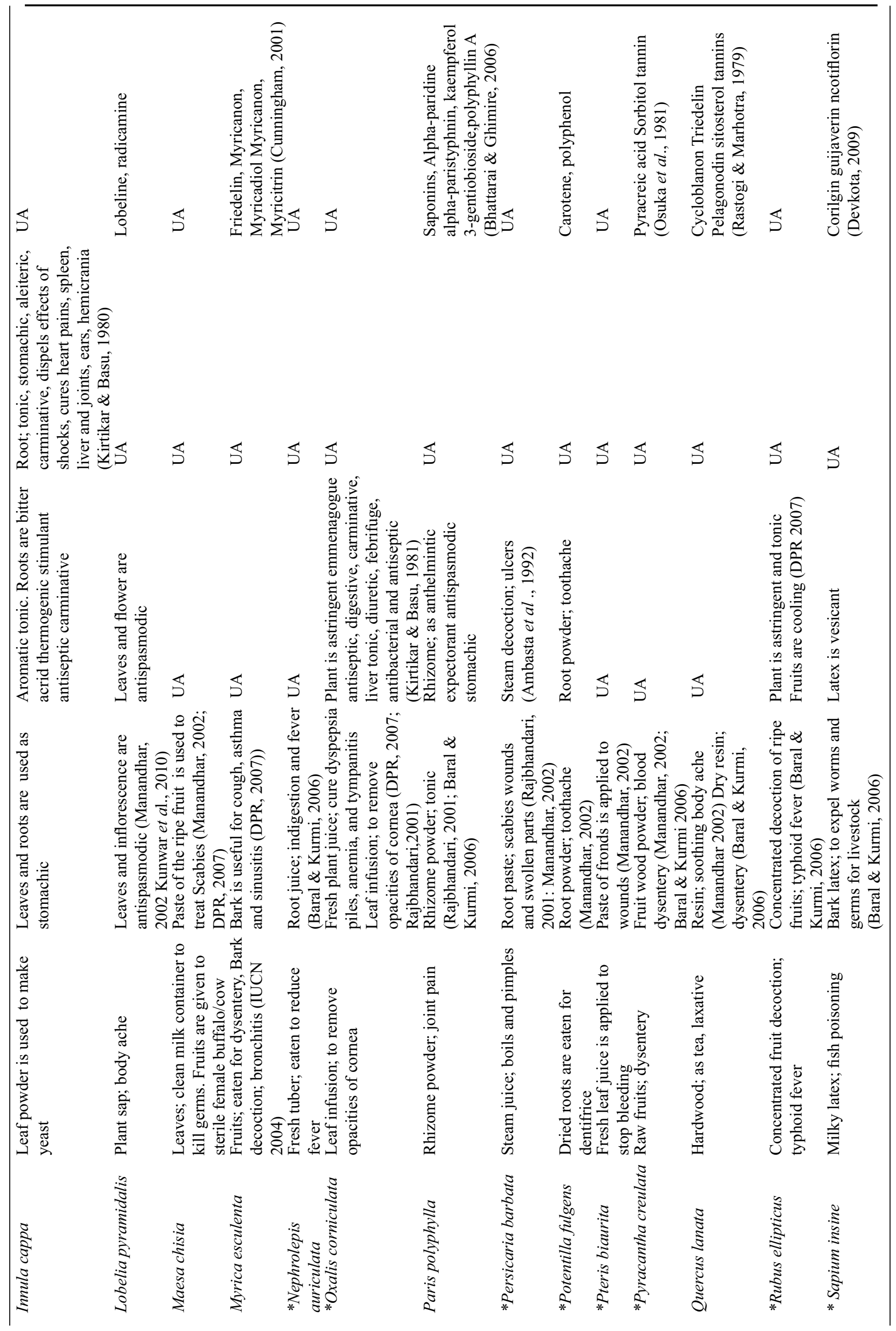



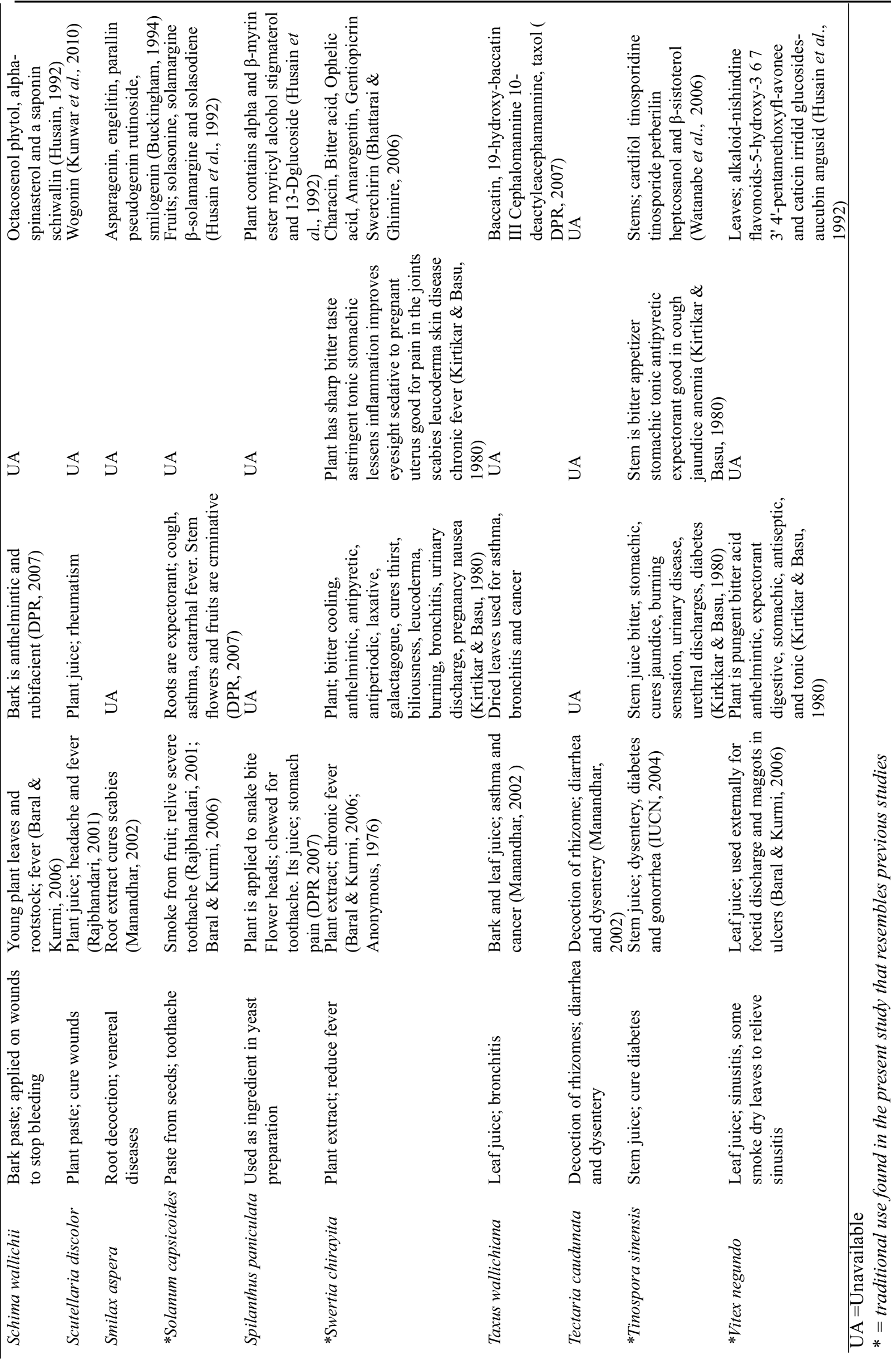